\title{
Behavioral Factors Influencing Stock Investment Decision of Individuals
}

\section{Prem Prasad Silwal $^{1}$ and Shreya Bajracharya ${ }^{2}$}

${ }^{1}$ Finance Associate, Nepal College of Management, Kathmandu University, Nepal, https://orcid.org/0000-0001-9482-6548 email: silwal.prem328@gmail.com

${ }^{2}$ Freelance researcher, corresponding email: bshreya@ncm.edu.np

Received on : September 20, 2021

Revised on : November 27, 2021

Accepted on : Dec 18, 2021

\section{Cite this paper}

Silwal, P.P. and Bajracharya, S. (2021).

Behavioral Factors Influencing Investment Decision of Individuals. International Research Journal of Management Science, vol.6(1), pp. 53-73

\begin{abstract}
Purpose: The purpose of this study is to identify the behavioral factors influencing individual investors' decisions and to analyze the relationship between these factors and investment decision performance.
\end{abstract}

Design/Methodology/Approach: The tested variables were: Anchoring bias, Gambler's Fallacy, Overconfidence bias, Availability and Representativeness bias from heuristics factor, Mental Accounting, Loss and Regret Aversion from prospect factor, and Market variables and Herding factors. The study employed exploratory and confirmatory factor analysis. In addition, structural equation modeling is applied for the testing of the hypotheses.

Findings: Prospect behavioral factor is seen to have negative correlation to investment performance. Herding, Market variables and Heuristic (including overconfidence and anchoring bias) are found to have positive correlation to investment performance.

Implications: This study provides compelling evidence that herding and heuristic approaches improve investment performance.
Keywords: Behavioral finance, Stock, Heuristics, Herding, Investment performance 


\section{Introduction}

Up until the late 1970's people believed only individuals, who are rational enough, would invest in the financial market [Ritter, (2003), Barberis \& Thaler (2005)]. One of the traditional theories refer to Efficient Market Hypothesis (EMH) which is an investment theory that states prices reflect all the information about the particular investment or market and that financial markets are efficient (Malkiel, 2003). However, Evans (2006), Gao and Schmidt (2005), Statman (1995, 1999), Tversky and Kahneman (1974) and Thaler (1994) show repeated patterns of irrationality, inconsistency and incompetence in the way human beings arrive at decisions and choices when faced with uncertainty (Waweru, 2008). Tversky and Kanheman (1976) exhibited that individuals often make decisions from simplified decision-making processes, called heuristics, and are vulnerable to cognitive biases (Vanessa et al., 2020). These supported the assumptions of individual's emotions and feelings playing (Fenton, Soane, Nicholson, \& Willman, 2011) a vital role in making decisions of our lives, whether it is personal or professional. Thus, Behavioral Finance emerged as a counter measure of traditional theories as it tries to rationalize the irrational behavior of investors (Tetlock, 2007) of large stock market. Investors' psychological reactions (Naseem, Mohsin, Hui, Liyan, \& Penglai, 2021) to the stock market, whether favorable or negative, can alter the economy's outlook.

Even for a small capital Market of Nepal, security market has boomed over the past few years. Severe fluctuations in the NEPSE Index over time has been seen for the past 23 years of operations. The Index during 1996 was 176.3 and 1102.64 in 2021 (NEPSE,2021). It shows a gain of 525\% over 22 years. After the 22-year growth of the Nepal Stock Market, Nepalese investors' decisions are still difficult for financial analysts to understand. Many experts explain the fluctuations as the cyclic nature of share market. According to records, NEPSE had remained bearish for few years, but the year 2020 kicked off with a bullish trend, the stock exchange making it to 1632 points on February 27 even amidst the pandemic (Bist,2020). At early 2014, the capital market reported an increasing trend for the NEPSE Index as well as the trading volumes. But by Mid- August of 2014, the indicators started to decline. During this period, the listed companies report their earnings and declare dividends. And they did show an increase in their profits and well as declared handsome dividends that make it favorable for market growth as predicted by previous trends in the market. But the market trend at that period showed a different scenario. The trend of NEPSE index for beginning 12 years show increase in index value by near to three times within one and half years during the bullish trends of 2007-08 and 2013-14. During 2007-08, it also reversed at a higher speed (Phuyal, 2014). We can clearly observe the fluctuation patterns in the following graph as well: 


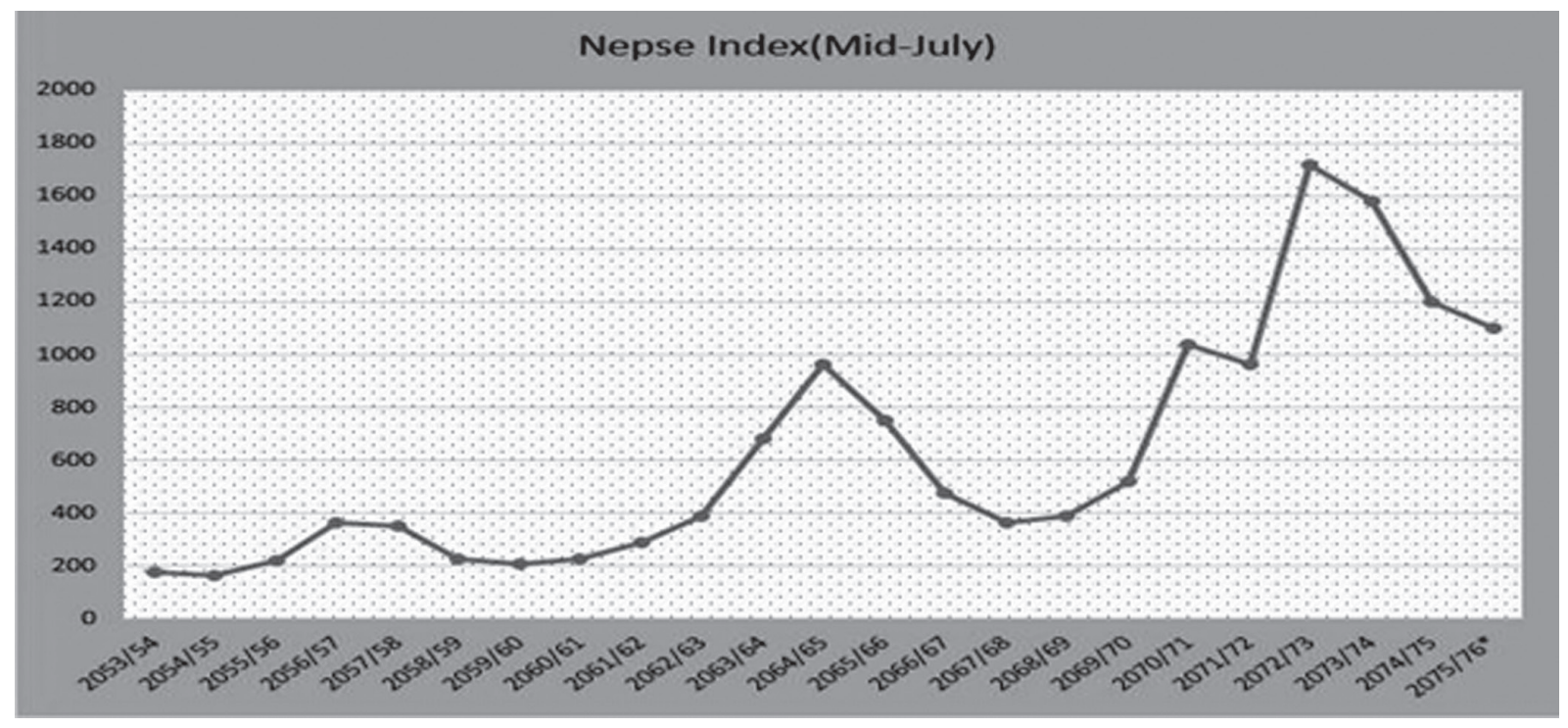

Figure 1.1 NEPSE Index from 2053-2076/ 1996 to 2020(Source: www.investopaper.com)

Seeing the reports and trends of NEPSE, it makes it harder to follow the theories which assume that investors rationally maximize their wealth by following basic financial rules and making investment decision on the risk-return consideration. The ups and downs in the indicators of the stock market are a regular phenomenon and the market goes up when more investors exercise for buying stocks and slips down when more investors are in the mood to sell their shares (Phuyal, 2014). This said mood of different individuals and the variant in information analysis by them causes the differences in the demand for and supply of the shares leading to the heavy fluctuations of the stock market.

Another important hypothesis for the stock market to be this heavily fluctuated in Nepal may be due to the term defined as "The Fear of Missing Out". The urge to invest in shares has increased and declined respectively to not to miss out on the opportunity to earn more and by following a crowd that said there would be potential losses in the future.

Many researchers, Vaidya (2021), Pandit, (2021) Sattar, Toseef, and Sattar, (2020), among others have considered Behavior Finance as a good theory to explain cognitive errors in investment decision making. First, Le and Doan (2011) found market factor to have a high influence on individual investing at a Vietnamese stock exchange and Herding, Prospect, Overconfidence-gamble's fallacy, and Anchoring bias to have moderate influence. Similarly, Prosad, Kapoor and Sengupta (2013) found the presence and impact of the disposition effect and overconfidence biases in Indian equity market that has led to an increase in trading volume at market level as well as at individual security level. 
Most studies conducted till now have been carried out in developed markets of Europe and USA ((Odean (1999); Rockenbach (2004); Caparrelli et al., (2004); Fogel and Berry (2006), Waweru, (2008)). And only few studies have been made on emerging markets, especially concerning of Asia. So, the research findings on behavioral bias and individual investment decisions of Nepalese based on the variables: market, prospect, and heuristics and herding are limited. It is, therefore, necessary to explore behavioral factors that impact on the decision-making process of individual investors at NEPSE to help the investors as well as security companies raise better predictions and decisions for their business. The purpose of this study is to explore the behavioral finance biases to influence investor decision in Nepal. As the concept of behavior finance is relatively new, to understand and give some suitable explanation for the investors' decisions is essential at the Nepal Stock Exchange.

This study is organized into five sections. Section 2 deals with the review of literature and the theoretical framework of this study, section 3 presents research methodology, overall analysis is presented in section 4 , and summary, conclusion and limitations of the study are shown in section 5 .

\section{Review of Literature}

The section deals with the review of theoretical and conceptual perspectives. Based on overall review of literature, a conceptual framework has been developed to govern the overall study in a more systematic manner.

\subsection{Efficient Market Hypothesis}

Efficient market theory states that the share prices reflect all the information of the market. According to the $\mathrm{EMH}$, stocks always trade at their fair value on exchanges, making it impossible for investors to purchase undervalued stocks or sell stocks for inflated prices. Moreover, it argues that markets become more efficient as the more participants engage in the market as higher number of people bring different types of information to bear on its price.

\subsection{Heuristics Decision Process}

Heuristics are simple rules of thumb, used for problem solving and decision-making using logic, that is unique from consequential logic. They do not guarantee optimal solutions, however, they have closer accuracy to solving more complex and difficult decision making. Especially when in need of quick decisions required or in case of uncertainty of the future, heuristics can be adopted. On the other hand, adopting this process may result in poorer decisions followed by biases or illusions such as: Representativeness, Gambler's fallacy, Anchoring, Overconfidence and Availability bias.

- Representativeness: It is a common information processing error where an individual believes that there is a higher correlation to the two similar events than they really are. 
- Gambler's Fallacy: This fallacy occurs when the individual believes a certain event is less likely or more likely to occur based on the outcome of the previous series of events.

- Anchoring: Anchoring effect is a cognitive bias where individuals' decision making is affected by a single point of anchor or also known as a reference point.

- Over confidence Bias: It is the tendency to hold false and misleading assessment of skills and intellect that falsely believes something is better than they actually are. Over confidence tends to make individuals less cautious in their investing decisions and is prone to making errors.

- Availability Bias: It is the tendency to use the information that arises to an individuals' mind quickly and easily while making decisions. Investors strongly prefer to invest in local companies where information is easily available is justified in this bias.

\subsection{Prospect Theory}

The prospect theory states that individuals are risk averse with respect to gains and risk acceptant with respect to the losses occurred in their investment making decisions. It hypothesizes that rational individuals give more weight to losses than compatible gains where people base their final decisions on the potential value of losses and gains rather than the final outcome. The key concepts of prospect theory include Mental Accounting, Loss Aversion and Regret.

- Mental Accounting: According to this, investors tend to hold onto assets on which they have experienced paper losses but are inclined to sell assets in which they have enjoyed gains.

- Loss Aversion: This states that the pain of losing is psychologically about twice as powerful as the power of gaining. Investors are fearful of losses that they are more willing to take risks to avoid losses than to make gains.

- Regret Theory: Regret refers to human behavior after they make a mistake. This can impact an investor's rational behavior as it can cause them either to be unnecessarily risk averse or to motivate to invest rashly. During extended bull markets, regret theory causes some investors to continue to invest heavily, ignoring signs of an impending crash.

\subsection{Herd Behavior Theory}

Herd Behavior theory states that individuals act according to the actions of others rather than use their personal information to act. Theory of herd behavior presumes that when deciding, an individual will act rationally given all the information he can acquire. It causes those involved to think and behave as everyone else around them. Investors follow what they perceive the other investors are doing, rather than relying on their own analysis. 


\subsection{Theoretical Framework}

Based on the mentioned studies, the following theoretical framework has been developed:

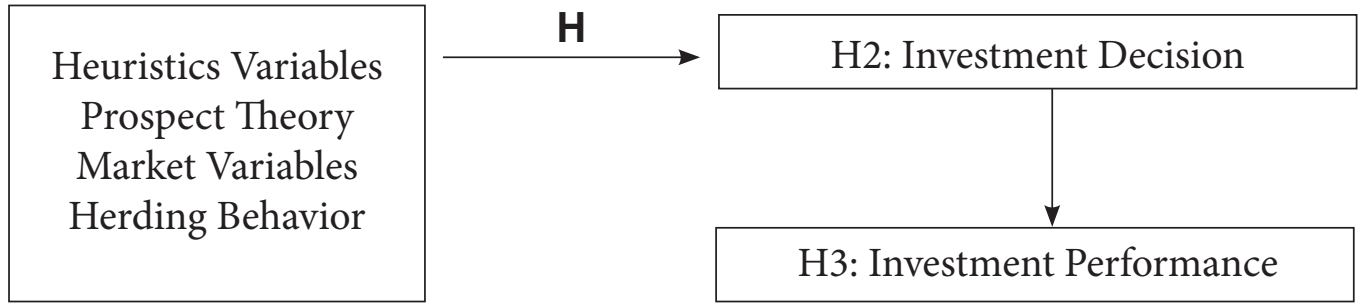

Fig 2.1 Conceptual Framework of behavioral factors impact on investment decision

\section{Research Methodology}

For this study, exploratory approach for exploring the behavioral factors, descriptive design to explain the investors' behavior using cross-sectional design that allows collecting and studying a relatively large sample size at once or single time has been used. This design allows collecting both qualitative and quantitative data that is measured with nominal and ordinal scales. For this, 5-point Likert scale is used in this research to evaluate the degrees of investors' agreement with impact on behavioral factor. The study is based on primary data with the use of questionnaire survey. The target population as of March 2021 are investors of 5 lakhs who transact at NEPSE. Further, convenience homogeneous sampling of 167 respondents' behavior has also been observed in the study. Due to potential estimate bias, convenience sampling alone cannot provide representative sample, thus the result cannot be generalized for the whole. However, the more homogeneous the convenience sampling is, the generalizable the sample can be and can reduce the chance of bias in sampling. The population being only the individuals, who invest at the stock market, is homogeneous in nature.

The questionnaire has been prepared in accordance with previous research of Waweru (2008), Phuoc (2011), and Nada (2013) for reliability and validity purposes. It has thus been divided into two parts: the first section contains respondents' information, and the behavioral factors influencing investment decisions are in second section.

\section{Empirical Results}

\subsection{Descriptive Statistics}

Out of 300 questionnaires distributed to individuals via e-forms on social media platforms, 167 investors responded, making the respondent rate as $55 \%$ which is moderately high. Table 4.1 shows the number of male investors to be higher than female investors in the sample (Male about $62 \%$ and Female about $38 \%$ ) which may raise questions regarding gender bias in the sampling frame for the study. The stock investors are mainly at the ages from 16 to 25 (133 investors that accounts for $80 \%$ of the total sample. This sample 
reflects the fact that a high proportion of individual investors at NEPSE are younger than 35 , and this study may highly reflect the investment behaviors of these investors.

\begin{tabular}{llll}
\hline Title & Category & Number & $\%$ \\
\hline Gender & Male & 105 & $62.90 \%$ \\
& Female & 62 & $37.10 \%$ \\
\hline Age & $16-25$ & 133 & $79.60 \%$ \\
& $26-35$ & 21 & $12.60 \%$ \\
& $36-45$ & 8 & $4.80 \%$ \\
& $46-55$ & 5 & $3 \%$ \\
& Above 55 & - & - \\
\hline Educational Qualification & High school and lower & 7 & $4.20 \%$ \\
& Undergraduate & 45 & $26.90 \%$ \\
& Bachelors & 96 & $57.50 \%$ \\
& PhD & - & - \\
& Master & 9 & $11.40 \%$ \\
\hline Years of experience & Under 3 years & 90 & $53.89 \%$ \\
& $3-5$ years & 27 & $16.17 \%$ \\
& $5-10$ years & 38 & $22.74 \%$ \\
& Over10 years & 12 & $7.20 \%$ \\
\hline Amount of Investment & Less than 20000 & 73 & $43.70 \%$ \\
& 20000-40000 & 19 & $11.40 \%$ \\
& $40000-60000$ & 15 & $9 \%$ \\
& $60000-80000$ & 14 & $8.40 \%$ \\
& $80000-100000$ & 5 & $3 \%$ \\
& Above 100000 & 41 & $24.60 \%$ \\
\hline
\end{tabular}

It also presents that a large proportion of the sample are investors who have attended the stock market for the duration less than 3 years, $16 \%$ of respondents for more than 3 years and less than 5 years, whereas, about $23 \%$ accounting for 5 to 10 years and $7 \%$, have been involved for more than 10 years. The higher percentages of individual investors in the surveyed sample invest with ranges from less than 20000(NPR) with $44 \%$, and $24.1 \%$ investing over 1 lakh rupees. 20.4\% investing from 20000 to under 60000, and $11.4 \%$ investing from 60000 to under 1. Overall, the respondents are higher proportion of the ages from 16 to 25 , who are generally the newcomers' stock investors. This is easy to acknowledge because of the booming participants at NEPSE in the recent yeas and is considered as emerging market as mentioned in Chapter 1. 


\section{Have you attended any course in the stock exchange?}

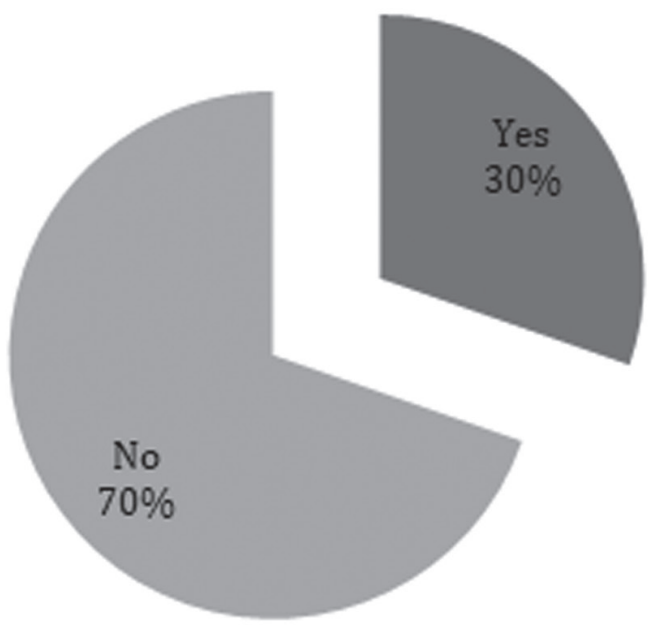

Fig 4.2 Proportion of respondents attending course of stock exchange

In addition to the demography of the sample, Figure 4.2 shows that the investors in the surveyed sample who already take the course of stock trading account for 30\% while those who have not yet taken any course are $70 \%$. Most of the investors seem to trade based on their own expertise than through professional classes to invest in the stock market at NEPSE.

\subsection{Factor Analysis of behavioral variables influencing investment decision and performance}

The questions from second part of the questionnaire are designed to explore the level of impact of behavioral variables on investment decision and performance of individuals. The questions are coded as $\mathrm{X} 1-\mathrm{X} 24$ and Y1-Y3 in the study. With Exploratory factor analysis (EFA) mentioned in methodology section, factor analysis is run to reduce or remove the unsuitable variables. The analysis results that the remaining variables are grouped into five factors (four factors of behavioral variables and one factor of investment performance), at $\mathrm{KMO}=0.755$ (sig. $=0.000$ ), $\%$ of total variance explained $=68.75 \%$, and all factors' loadings are more than 0.5 . The eigen values are also above 1 . These indexes prove that factor analysis for these variables is accepted. The result is presented in the Table 4.2 and 4.3. 
Table 4.2: Factor analysis for behavioral variables and investment performance

\begin{tabular}{|c|c|c|c|c|c|c|}
\hline \multirow{3}{*}{ Factors } & \multicolumn{6}{|c|}{ Rotated Component Matrix ${ }^{a}$} \\
\hline & \multirow{2}{*}{ Variables } & \multicolumn{5}{|c|}{ Component } \\
\hline & & F1 & F2 & F3 & F4 & F5 \\
\hline \multirow{4}{*}{ Prospect } & $\begin{array}{l}\text { X15: I feel nervous when } \\
\text { large price drops in my } \\
\text { invested stocks. }\end{array}$ & 0.895 & & & & \\
\hline & $\begin{array}{l}\text { X13: After a prior loss, I } \\
\text { become more risk averse } \\
\text { (avoid risks). }\end{array}$ & 0.868 & & & & \\
\hline & $\begin{array}{l}\text { X16: I avoid selling shares } \\
\text { that have decreased in } \\
\text { value. }\end{array}$ & 0.862 & & & & \\
\hline & $\begin{array}{l}\text { X14: I am more concerned } \\
\text { about a large loss in my } \\
\text { stock than missing a } \\
\text { substantial gain. }\end{array}$ & 0.860 & & & & \\
\hline \multirow{5}{*}{ Herding } & $\begin{array}{l}\text { X22: Other investors' } \\
\text { decisions of the stock } \\
\text { volume have impact on my } \\
\text { investment decisions. }\end{array}$ & & 0.895 & & & \\
\hline & $\begin{array}{l}\text { X23: Other investors' } \\
\text { decisions of choosing stock } \\
\text { types have impact on my } \\
\text { investment decisions. }\end{array}$ & & 0.877 & & & \\
\hline & $\begin{array}{l}\text { X24: I usually react quickly } \\
\text { to the changes of other } \\
\text { investors' decisions and } \\
\text { follow their reactions to the } \\
\text { stock market. }\end{array}$ & & 0.840 & & & \\
\hline & $\begin{array}{l}\text { X21: Other investors' } \\
\text { decisions of buying and } \\
\text { selling stocks have impact } \\
\text { on my investment } \\
\text { decisions. }\end{array}$ & & 0.714 & & & \\
\hline & $\begin{array}{l}\text { X20: Market information is } \\
\text { important for stock } \\
\text { investment to me. }\end{array}$ & & & 0.871 & & \\
\hline \multirow[t]{2}{*}{ Market } & $\begin{array}{l}\text { X18: I carefully consider } \\
\text { the price changes of stocks } \\
\text { that I intend to invest in. }\end{array}$ & & & 0.820 & & \\
\hline & $\begin{array}{l}\text { X19: I put the past trends of } \\
\text { stocks under consideration } \\
\text { for my investment. }\end{array}$ & & & 0.803 & & \\
\hline
\end{tabular}




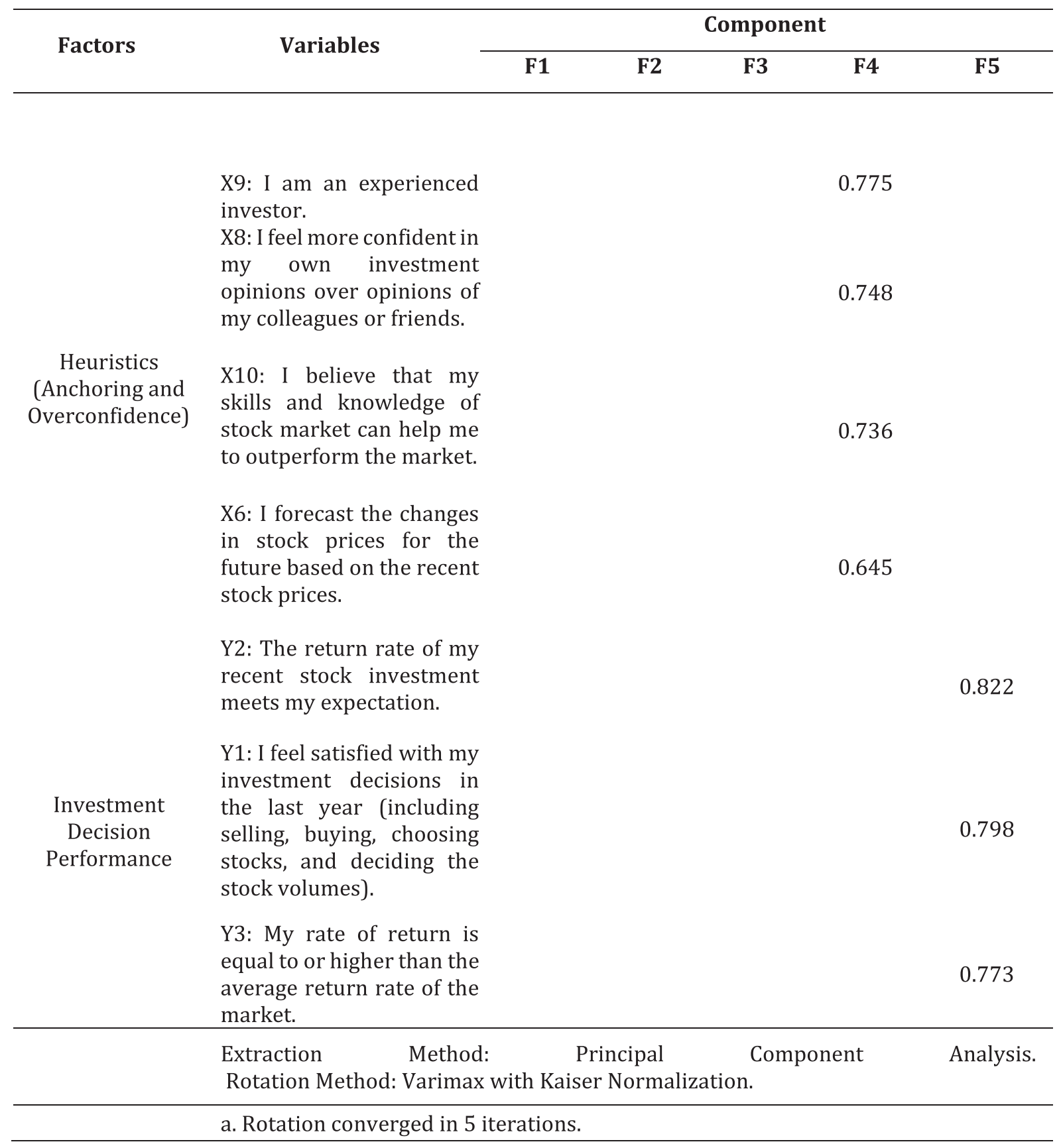


Table 4.3: KMO \& Bartlett's Test

\begin{tabular}{llc}
\hline \hline Kaiser-Meyer-Olkin Measure of Sampling Adequacy. & & 0.755 \\
Bartlett's Test of Sphericity & Approx. Chi-Square & 1674.118 \\
& Df & 351 \\
& Sig. & 0.000 \\
\hline \hline
\end{tabular}

Table 4.4 Total variance explained for factors

\begin{tabular}{|c|c|c|c|c|c|c|}
\hline & & $\begin{array}{c}\text { Prospect } \\
\text { (F1) }\end{array}$ & $\begin{array}{c}\text { Herding } \\
\text { (F2) }\end{array}$ & $\begin{array}{c}\text { Market } \\
\text { (F3) }\end{array}$ & $\begin{array}{c}\text { Heuristics } \\
\text { (F4) }\end{array}$ & $\begin{array}{c}\text { Investment } \\
\text { Decision } \\
\text { (F5) }\end{array}$ \\
\hline Eigen Value & & 4.155 & 2.615 & 2.360 & 1.751 & 1.493 \\
\hline $\begin{array}{l}\text { Proportion of } \\
\text { explained (\%) }\end{array}$ & Variance & 23.085 & 14.527 & 13.113 & 9.729 & 8.295 \\
\hline $\begin{array}{l}\text { Cumulative } \\
\text { explained (\%) }\end{array}$ & Variance & 23.085 & 37.613 & 50.726 & 60.455 & 68.750 \\
\hline
\end{tabular}

As shown in the Table 4.2, the variables of herding, heuristics, prospect, and market are grouped into only one respectively related factor. Some of the variables that are less than 0.5 have been removed and these results illustrate the influence of individual behavior in investment decision. Over confidence and Anchoring Bias from heuristics and Loss aversion and Regret aversion from prospect theory have more influence than any other variables in these factors. This supports hypothesis $\mathrm{H} 1$ that states the behavioral variables that influence the investment decisions of individuals are theoretically formed into four groups known as herding, prospect, market, and heuristic. Accordingly, there are four behavioral factors that impact the investment decisions of individual investors at the Nepal Stock Exchange. In the herding factor, all four original variables (X21 to X24), all in market variable (X18 to X20), two out of seven prospect items (X13 to X16), four out of ten heuristics variables (X6, X8 to X10, and all the variables of investment performance (Y1, Y2 and Y3) are accepted by factor analysis. 


\subsection{Reliability Analysis}

In this part, Cronbach's alpha is calculated to test the reliability of the items included by factors in the above analysis. The Cronbach's alpha is interpreted as a coefficient alpha and its value ranges from 0 to 1.

Table 4.5: The results of Cronbach's Alpha

\begin{tabular}{|c|c|c|c|c|}
\hline Factors & Variables & $\begin{array}{c}\text { Cronbach's } \\
\text { Alpha }\end{array}$ & $\begin{array}{c}\text { Corrected Item- } \\
\text { Total } \\
\text { correlation }\end{array}$ & $\begin{array}{c}\text { Cronbach's } \\
\text { Alpha if item } \\
\text { deleted }\end{array}$ \\
\hline & $\mathrm{X} 6$ & \multirow{4}{*}{0.789} & 0.537 & 0.767 \\
\hline Overconfidence \& & $\mathrm{X} 8$ & & 0.607 & 0.734 \\
\hline \multirow[t]{2}{*}{ Anchoring (Heuristics) } & X9 & & 0.627 & 0.727 \\
\hline & $\mathrm{X} 10$ & & 0.649 & 0.718 \\
\hline \multirow{4}{*}{ Herding } & $\mathrm{X} 21$ & \multirow{4}{*}{0.858} & 0.564 & 0.878 \\
\hline & $\mathrm{X} 22$ & & 0.788 & 0.783 \\
\hline & $\mathrm{X} 23$ & & 0.770 & 0.789 \\
\hline & $\mathrm{X} 24$ & & 0.702 & 0.819 \\
\hline \multirow{3}{*}{ Market } & $\mathrm{X} 18$ & \multirow{3}{*}{0.81} & 0.655 & 0.740 \\
\hline & X19 & & 0.619 & 0.775 \\
\hline & $\mathrm{X} 20$ & & 0.697 & 0.693 \\
\hline \multirow{4}{*}{ Prospect } & $\mathrm{X} 13$ & \multirow{4}{*}{0.911} & 0.804 & 0.882 \\
\hline & $\mathrm{X} 14$ & & 0.808 & 0.880 \\
\hline & $\mathrm{X} 15$ & & 0.793 & 0.886 \\
\hline & $\mathrm{X} 16$ & & 0.785 & 0.889 \\
\hline \multirow{3}{*}{$\begin{array}{c}\text { Investment Decision } \\
\text { \& Performance }\end{array}$} & Y1 & \multirow{3}{*}{0.82} & 0.552 & 0.627 \\
\hline & Y2 & & 0.603 & 0.551 \\
\hline & Y3 & & 0.498 & 0.694 \\
\hline
\end{tabular}

Table 4.5 presents the consistency of the items of each factor calculated using Cronbach's alpha whose all factors are greater 0.6. Therefore, the results of reliability analysis confirmed that consistency is at an acceptable level for each factor: Herding, Prospect, Market, Overconfidence and Anchoring, and Investment Performance are reliable enough to follow further analysis. 


\subsection{Impact Levels of Behavioral Factors on the Individual Investment Decisions and Scores of Investment Performance}

The impact levels of behavioral variables on the investment decisions are identified by calculating the values of sample mean of each variable. Mean values that are 1-1.80 shows that the variables have very low impact, mean values from 1.81 to 2.60 shows that the variables have low impacts, 2.61 to 3.40 show moderate impacts. Similarly, mean values from 3.41 to 4.20 show high impact and mean 4.21 to 5 show very high impact.

\subsubsection{Impact of Heuristics on Investment Decision}

Table 4.6: Impact of Heuristic Variables on the investment decision-making

\begin{tabular}{|c|c|c|c|}
\hline Factor & Variables & Mean & $\begin{array}{c}\text { Std. } \\
\text { Deviation }\end{array}$ \\
\hline \multirow{4}{*}{ Heuristics } & $\begin{array}{l}\text { X6: I forecast the changes in stock prices for the future } \\
\text { based on the recent stock prices. }\end{array}$ & 3.81 & 0.756 \\
\hline & $\begin{array}{l}\text { X8: I feel more confident in my own investment opinions } \\
\text { over opinions of my colleagues or friends. }\end{array}$ & 4.00 & 0.873 \\
\hline & X9: I am an experienced investor. & 3.20 & 1.121 \\
\hline & $\begin{array}{l}\text { X10: I believe that my skills and knowledge of stock } \\
\text { market can help me to outperform the market. }\end{array}$ & 3.86 & 0.734 \\
\hline
\end{tabular}

Table 4.6 shows that anchoring has a high impact on individual investment decision making where investors rely on their previous stock prices in the market for their next investment with mean of 3.81. Overconfidence also has a high impact on investment decision making with average mean of 3.7. Individuals are highly confident on their own investment opinion over information from other sources, and believe they are experienced in it and can outperform the market. 


\subsubsection{Impact of Prospect Variables on the investment decision making}

Table 4.7: Impacts of Prospect Variables on the investment decision-making

\begin{tabular}{|c|c|c|c|}
\hline Factor & Variables & Mean & $\begin{array}{c}\text { Std. } \\
\text { Deviation }\end{array}$ \\
\hline \multirow{4}{*}{ Prospect } & $\begin{array}{l}\text { X13: After a prior loss, I become more risk averse (avoid } \\
\text { risks). }\end{array}$ & 3.93 & 0.977 \\
\hline & $\begin{array}{l}\text { X14: I am more concerned about a large loss in my stock } \\
\text { than missing a substantial gain. }\end{array}$ & 3.92 & 0.985 \\
\hline & $\begin{array}{l}\text { X15: I feel nervous when large price drops in my } \\
\text { invested stocks. }\end{array}$ & 3.83 & 0.962 \\
\hline & X16: I avoid selling shares that have decreased in value. & 3.91 & 0.921 \\
\hline
\end{tabular}

In the dimension of Prospect, loss aversion and regret aversion have their representative variables influencing the decision making of investors' stock investment. Individual investors at NEPSE have loss aversion (X13 to X15), and regret aversion (X16) at high degree, with the mean of each variable of 3.89 and 3.91 respectively. Especially, the investors have a high tendency of becoming more loss averse with increase in their losses and are more concerned of losses than gain.

\subsubsection{Impacts of Market Variables on the investment decision making}

Table 4.8: Impacts of Market Variables on the investment decision-making

\begin{tabular}{|c|c|c|c|}
\hline Market & Variables & Mean & $\begin{array}{c}\text { Std. } \\
\text { Deviation }\end{array}$ \\
\hline \multirow{3}{*}{ Market } & $\begin{array}{l}\text { X18: I consider carefully the price changes of stocks that } \\
\text { I intend to invest in. }\end{array}$ & 4.22 & 0.652 \\
\hline & $\begin{array}{l}\text { X19: I put the past trends of stocks under consideration } \\
\text { for my investment. }\end{array}$ & 4.27 & 0.686 \\
\hline & $\begin{array}{l}\text { X20: Market information is important for stock } \\
\text { investment to me. }\end{array}$ & 4.33 & 0.696 \\
\hline
\end{tabular}

Table 4.8 reveals that market factor impacts on the investment decision making of individual investors at very high rate with means $4.22,4.27$ and 4.33 . This means the individuals tend to consider the information of stock market: general information, past trends of stock price and current stock price changes very carefully before making their investment decision. 


\subsubsection{Impact of Herding Variables on the investment decision making} Table 4.9 Impacts of Herding Variables on the investment decision-making

\begin{tabular}{|c|c|c|c|}
\hline Factor & Variables & Mean & $\begin{array}{c}\text { Std. } \\
\text { Deviation }\end{array}$ \\
\hline \multirow{4}{*}{ Herding } & $\begin{array}{l}\text { X21: Other investors' decisions of buying and selling stocks } \\
\text { have impact on my investment decisions. }\end{array}$ & 4.10 & 0.864 \\
\hline & $\begin{array}{l}\text { X22: Other investors' decisions of the stock volume have } \\
\text { impact on my investment decisions. }\end{array}$ & 3.82 & 0.804 \\
\hline & $\begin{array}{l}\text { X23: Other investors' decisions of choosing stock types } \\
\text { have impact on my investment decisions. }\end{array}$ & 2.65 & 0.844 \\
\hline & $\begin{array}{l}\text { X24: I usually react quickly to the changes of other } \\
\text { investors' decisions and follow their reactions to the stock } \\
\text { market. }\end{array}$ & 2.66 & 0.780 \\
\hline
\end{tabular}

As shown in Table 4.9, individual investors at NEPSE follow highly of the other investors' trading decisions. They tend to consider others' behaviors of choosing types of stock (X21, mean $=4.10)$ more than other herding behavior. Stock volume for trading (X22) is also high at mean 3.82. Similarly, the investors moderately follow others' decisions of buying and selling stocks with mean 2.65. Moreover, herding effect tends to impact quickly on other's decisions of stock investment with the mean of 2.66.

In conclusion, the behavioral variables support hypothesis $\mathrm{H} 2$ as of four factors: Heuristics, Prospect, and Herding have high to moderate impacts on individual investors' decision making at NEPSE. 


\subsubsection{Investment Performance}

Table 4.10: Investment performance

\begin{tabular}{|c|c|c|c|}
\hline Factor & Variables & Mean & $\begin{array}{c}\text { Std. } \\
\text { Deviation }\end{array}$ \\
\hline \multirow{3}{*}{$\begin{array}{l}\text { Investment } \\
\text { Performance }\end{array}$} & $\begin{array}{l}\text { Y1: I feel satisfied with my investment decisions in the } \\
\text { last year (including selling, buying, choosing stocks, and } \\
\text { deciding the stock volumes). }\end{array}$ & 3.35 & 0.710 \\
\hline & $\begin{array}{l}\text { Y2: The return rate of my recent stock investment meets } \\
\text { my expectation. }\end{array}$ & 3.07 & 0.674 \\
\hline & $\begin{array}{l}\text { Y3: My rate of return is equal to or higher than the } \\
\text { average return rate of the market. }\end{array}$ & 3.79 & 0.515 \\
\hline
\end{tabular}

Table 4.10 shows individual investors' expectations have moderate investment return rates in comparison to their expectations (Y2) with mean 3.07 and the average return rate of the market is highest (Y3) with mean 3.79. Moreover, they are not yet felt fully satisfied with their investment decisions (including selling, buying, choosing stocks, and deciding the stock volumes) in the recent year with moderate mean of 3.35 (Y1). Therefore, the investment performance could be improved by considering the influences of behavioral factors.

4.6 Influence of Behavioral Factors on the Individual Investment Performance In this section, Structural Equation Modeling (SEM) is used to portray relationships among the variables by combining multiple regression and factor analysis to one model. The structural model fit is very good with GFI $=0.952$; $\mathrm{TLI}=0.96 ; \mathrm{CFI}=0.963 ; \mathrm{RMSEA}=0.05$, and $\mathrm{CMIN} / \mathrm{df}=1.4$. These indexes indicate a strong predictive validity of the model for the surveyed data. The more detailed tables of SEM done by AMOS are presented in the Appendix C. 
The results of SEM done by AMOS are presented in the Figure 4.2.

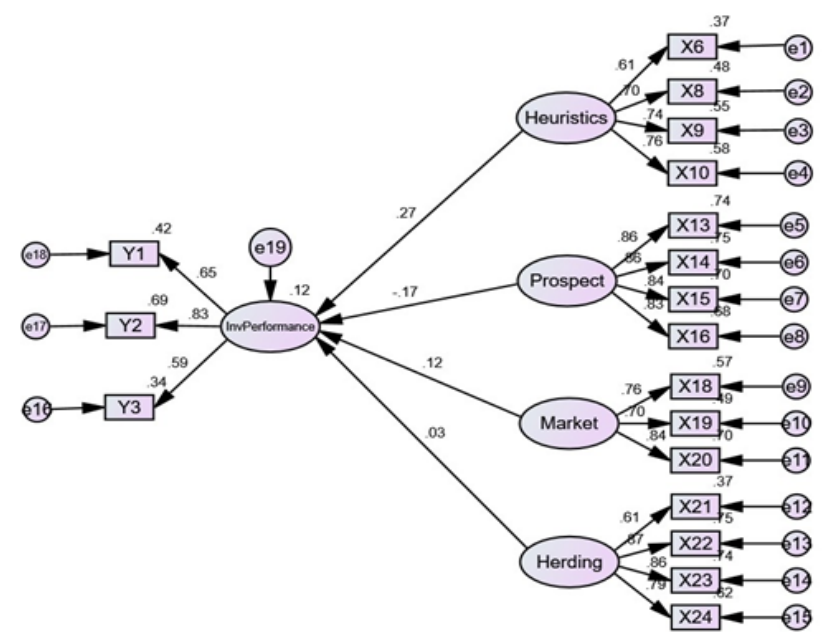

Figure 4.2: Structural Equations Modeling for Behavioral Factors and Investment Performance

Figure 4.2 gives the estimates of factor loadings, regression weights between variables as well as the variances of each variable explained by the other variables. In the model, four factors are explored to have impacts on Investment Performance: Herding (including X21, X22, X23, and X24), Prospect (X14, X14, X15 and X16), Market (X18, X19 and X20) and Heuristic (including X6, X8, X9 and X10).

The factor loadings between each factor and its variables are all over 0.5 that ensures the convergent validity of data measurements. The heuristic behaviors which are related to Overconfidence and Anchoring Bias have the highest positive and significant impact on the investment performance with the regression estimate of 0.27 (sig. $=0.01$ ). The herding behaviors also influence positively and significantly on the investment performance with the regression estimate of 0.03 (sig.= 0.04 ) while the prospect behaviors including Loss aversion and Regret aversion give the negative but significant impact on the investment performance with the regression estimate of -0.17 (sig.= 0.01 ). Market has positive and significant influence with regression estimate of $0.12(\mathrm{sig}=0.000)$. All these behaviors can explain $12 \%$ of the variance of the individual investors' performance.

The results given by SEM supports the hypothesis $\mathrm{H} 3$ that mentions that all behavioral factors have significant impacts on the investment performance as all factors of market and heuristic are believed to have positive influences while herding has low influence on investment performance while prospect factor have negative influence. 


\section{Conclusion}

This study supports the view that the behavior of the institutional investors is affected by various factors. It found that there are four behavioral factors that impact the investment decisions of individual investors at NEPSE: Heuristics, Prospect, Market and Herding. Heuristics contain two major variables known as Overconfidence and Anchoring Bias, Prospect possess Loss and Regret Aversion Variables, Market refers to market information and herding include choice of trading stocks, volume of trading stocks, buying, and selling of stocks. More specifically, Herding (Overconfidence-Anchoring), Market, Prospect have high impact on individual investors decision making. However, type of stock and reaction to others decision has a lower impact than any other in the herding factor.

Individual investors were seen to be confident of their investments but risk averse doing potential losses. They rely highly on information available in the market about stock prices and base their decisions on market factors greatly. Herding behavior is existent when making investment decisions especially related to buying and selling of stocks. Furthermore, Heuristics and Market has shown higher positive correlation to investment performance with herding following at low levels. However, prospect variable has negative correlation to the investment performance which can be explained by hasty decision after gains to result in poor decisions. Most of the findings are consistent with those of studies (Tetlock (2007), Vaidya (2021), Pandit, (2021) Sattar, Toseef, and Sattar, (2020)), carried out in the major economies. However, the sub behavioral factors are seen to vary according to economies when compared. It is recommended to study further on the relation between the type of economies and the numerous subcategories of behavior shown in them.

\section{Limitations and future implications}

This study was conducted using a 5-point Likert scale to measure the behavioral factors impact on investment decision and performance. It is essential to have further research to confirm the findings of this research by using a different Likert scale measurement to compare the findings and diversify the knowledge. Larger sample size research should be taken to generalize the sample findings to population and diversify the respondents. Human mind is complex to understand, and their reaction depends completely on the current situation which limits the true correct intention while answering the questions in the Likert scale during the study. So, researchers are suggested to take this into light for further analysis. Similarly, this study comprised only individual investors at NEPSE, however, future research could be conducted after using institutional investors (such as broker house, banks, and security companies) behavior pattern who equally carry more information about the impacts of financial behaviors on the Nepalese security market. Factors such as cultural differences, financial ability, and economy types could be taken into consideration for expanding the horizon of this area. 


\section{Reference}

Albar, F. M., \&Jetter, A. J. (2009). Heuristics in decision making. Paper presented at the PICMET'09-2009 Portland International Conference on Management of Engineering \& Technology.

Bakar, S., \& Yi, A. N. C. (2016). The impact of psychological factors on investors' decision making in Malaysian stock market: a case of Klang Valley and Pahang. Procedia Economics and Finance, 35, 319-328.

Barberis, N., \& Thaler, R. (2005). A survey of behavioral finance (pp. 1-76). Princeton University Press.

Chen, G., Kim, K. A., Nofsinger, J. R., \& Rui, O. M. (2007). Trading performance, disposition effect, overconfidence, representativeness bias, and experience of emerging market investors. Journal of behavioral decision making, 20(4), 425-451.

Chong, T. T.-L., Liu, X., \& Zhu, C. (2017). What explains herd behavior in the Chinese stock market? Journal of Behavioral Finance, 18(4), 448-456.

Evans, D. A. (2006). Subject perceptions of confidence and predictive validity in financial information cues. The Journal of Behavioral Finance, 7(1), 12-28.

Fenton-O'Creevy, M., Soane, E., Nicholson, N., \& Willman, P. (2011). Thinking, feeling and deciding: The influence of emotions on the decision making and performance of traders. Journal of Organizational Behavior, 32(8), 1044-1061.

Gao, L., \& Schmidt, U. (2005). Self is never neutral: why economic agents behave irrationally. The Journal of Behavioral Finance, 6(1), 27-37.

Ghauri, P., Grønhaug, K., \& Strange, R. (2020). Research methods in business studies: Cambridge University Press.

Islamia, J. (2016). Research design. Research in Social Science: Interdisciplinary Perspectives. Department of Political Science, Faculty of Social Sciences.

Jager, J., Putnick, D. L., \& Bornstein, M. H. (2017). II. More than just convenient: The scientific merits of homogeneous convenience samples. Monographs of the Society for Research in Child Development, 82(2), 13-30.

Javaira, Z., \& Hassan, A. (2015). An examination of herding behavior in Pakistani stock market. International journal of emerging markets.

Kabir, S. M. S. (2016). Basic Guidelines for Research. An Introductory Approach for All Disciplines, 168180.

Kengatharan, L., \&Kengatharan, N. (2014). The influence of behavioral factors in making investment decisions and performance: Study on investors of Colombo Stock Exchange, Sri Lanka. Asian Journal of Finance \& Accounting, 6(1), 1.

Khan, S. (2016). Why do you use 5-point Likert scale and not 7-point Likert scale for getting responses? 
Retrieved from https://www.researchgate.net

Le Luong, P., \&Thi Thu Ha, D. (2011). Behavioral factors influencing individual investors' decision-making and performance.: A survey at the Ho Chi Minh Stock Exchange.

Levy, J. S. (1992). An introduction to prospect theory. Political psychology, 171-186.

Lingesiya, K., \&Navaneethakrishnan, K. (2014). The Influence of Behavioral Factors in Making Investment Decisions and Performance: Study on Investors of Colombo Stock Exchange, Sri Lanka.

Litimi, H. (2017). Herd behavior in the French stock market. Review of Accounting and Finance, 16 (4), 497-515.

Malkiel, B. G. (2003). The efficient market hypothesis and its critics. Journal of economic perspectives, $17(1), 59-82$.

Naseem, S., Mohsin, M., Hui, W., Liyan, G., \& Penglai, K. (2021). The investor psychology and stock market behavior during the initial era of COVID-19: a study of China, Japan, and the United States. Frontiers in Psychology, 12, 16.

Pandit, K. C. (2021). Trading practice and Behavioral Biases of Individual Investors in Nepalese Stock Market. Nepalese Journal of Management Research, 1, 55-62.

Pandit, K. C., \& Chitwan, N. (2018). Influence of Trading Practice and Demographic Variables on Behavioral Biases of individual investors in Nepalese Stock Market Journal of Balkumari College. JOURNAL OF BALKUMARI COLLEGE.

Phuyal, P. (2017). Study of investors at NEPSE. PhD dissertation. Faculty of Management, Tribhuvan University.

Pochea, M.-M., Filip, A.-M., \&Pece, A.-M. (2017). Herding behavior in CEE stock markets under asymmetric conditions: a quantile regression analysis. Journal of Behavioral Finance, 18(4), 400-416.

Pokharel, P. R. (2020). Behavioral Factors and Investment Decision: A Case of Nepal. Available at SSRN 3687104.

Prosad, J. M., Kapoor, S., Sengupta, J., \& Roychoudhary, S. (2017). Overconfidence and disposition effect in Indian equity market: An empirical evidence. Global Business Review, 19(5), 1303-1321.

Ritter, J. R. (2003). Behavioral finance. Pacific-Basin finance journal, 11(4), 429-437.

Ritter, J. R. (2003). Behavioral finance. Pacific-Basin finance journal, 11(4), 429-437.

Rompotis, G. G. (2018). Herding behavior among exchange-traded funds. Journal of Behavioral Finance, 19(4), 483-497.

Rottenstreich, Y., \& Tversky, A. (1997). Unpacking, repacking, and anchoring: Advances in support theory. Psychological review, 104(2), 406.

Salman, M., Khan, B., Khan, S. Z., \& Khan, R. U. The impact of heuristic availability bias on investment decision-making: Moderated mediation model. Business Strategy \& Development. 
Sattar, M. A., Toseef, M., \& Sattar, M. F. (2020). Behavioral Finance Biases in Investment Decision Making. International Journal of Accounting, Finance and Risk Management, 5(2), 69.

Saunders, M., Lewis, P., \& Thornhill, A. (2009). Research methods for business students: Pearson education.

Shams, M. F., Kordlouie, H., \&Dezfuli, H. K. (2012). The Effect of Mental Accounting on Sales Decisions of Stockholders in Tehran Stock Exchange. World Applied Sciences Journal, 20(6), 842-847.

Statman, M. (1999). Behaviorial finance: Past battles and future engagements. Financial analysts journal, 55(6), 18-27.

Tetlock, P. C. (2007). Giving content to investor sentiment: The role of media in the stock market. The Journal of finance, 62(3), 1139-1168.

Tversky, A., \& Kahneman, D. (1974). Judgment under uncertainty: Heuristics and biases. science, 185(4157), 1124-1131.

Vaidya, R. (2021). Qualitative Analysis on Investment Decisions of Nepalese Stock Market Investors. Journal of Business and Management Review, 2(5), 349-365.

Valcanover, V. M., Sonza, I. B., \& da Silva, W. V. (2020). Behavioral Finance Experiments: A Recent Systematic Literature Review. SAGE Open, 10(4), 2158244020969672.

Vo, X. V., \& Phan, D. B. A. (2017). Further evidence on the herd behavior in Vietnam stock market. Journal of Behavioral and Experimental Finance, 13, 33-41.

Walden, E. A., \& Browne, G. J. (2009). Sequential adoption theory: a theory for understanding herding behavior in early adoption of novel technologies. Journal of the Association for Information Systems, $10(1), 1$.

Waweru, N. M., Munyoki, E., \&Uliana, E. (2008). The effects of behavioral factors in investment decision-making: a survey of institutional investors operating at the Nairobi Stock Exchange. International Journal of Business and Emerging Markets, 1(1), 24-41.

Xu, Y., Chen, G., \& Rui, O. M. (2004). When Will Investors Herd? Evidence from the Chinese Stock Markets: School of Economics and Finance, University of Hong Kong. 